\title{
A importância da leitura na vida acadêmica e cotidiana
}

\author{
The importance of Reading at academic and daily life
}

\author{
Anselmo Gomes de OLIVEIRA; \\ Dâmaris SILVEIRA \\ Editores
}

A leitura começa a ter uma grande importância no Universo de nossas vidas desde os desde os primeiros momentos em que viemos ao mundo e começamos a "ler", a interpretar e sentir o que está ao nosso redor no meio ambiente e o que é importante para nós naquele momento. Esse é o princípio do amadurecimento de nosso sistema nervoso, que evolui gradativamente com o tempo, passando a "ler" os estímulos do meio e a interpretar seus significados para o organismo e a responder cada estímulo de forma sequencialmente mais dedicada e precisa até atingir seu ápice de amadurecimento, quando onde esse conjunto de atividades pode ser executado em alguns milésimos de segundos. Evidentemente esse é um significado figurado da leitura, mas também envolve o significado da exploração do meio e acumulo de informações, as quais podem ser utilizadas no momento ou no futuro.

No mundo globalizado, a leitura representa um dos instrumentos essenciais para o desenvolvimento do caráter crítico do indivíduo o qual lhe permitirá questionar e contribuir com a evolução de determinado assunto. A leitura proporciona, então, uma amplitude de informações originadas de fontes com olhares diferentes sobre determinado assunto. Essa construção de conhecimento reveste-se de uma fonte inesgotável de experiências, as quais são elementos essenciais na construção e domínio do conhecimento do indivíduo ampliando sua visão e os horizontes na vida cotidiana.

Entretanto, a leitura pode se manifestar de formas diferentes, do que a simples leitura de textos. Pode ser igualmente informativo o olhar sobre uma figura retratada sobre uma tela, quando assistimos a um filme, quando olhamos uma fotografia, ou quando temos alguma percepção dos aspectos do mundo que nos cerca. Antes de tudo, ler é perceber e entender tudo aquilo que nos envolve fisicamente e mentalmente.

Na vida acadêmica, a leitura é um elemento imprescindível para a fixação e ampliação dos conteúdos ministrados. O conhecimento de fontes adicionais constitui a grande base de apoio para a abstração de conceitos, ideias e domínio amplo em relação ao assunto. $\mathrm{O}$ significado da leitura na construção do conhecimento científico vai muito além da simples leitura de textos de outros autores, mas sim na capacidade do leitor na análise crítica, na interpretação e no relacionamento com o conteúdo do trabalho que está sendo construído.

Assim, a facilidade com que alguns autores expõem seus resultados experimentais e suas ideias, e discutem sua inter-relação e sua inserção na literatura especializada, certamente está relacionada com o conhecimento acumulado em torno do assunto. A construção de textos de revisão sobre um assunto pontual, não deve apenas envolver a exposição da absorção "osmótica" do conhecimento produzido por outros autores, mas deve obrigatoriamente também expor a contribuição específica dos autores sobre o assunto.

De forma geral a qualidade dos textos científicos está relacionada com maturidade e consolidação dos autores em torno da ciência envolvida no trabalho, as quais se expressam por meio da associação da experiência pessoal dos autores com seus resultados experimentais e com a leitura da experiência de outros autores.

Os artigos preparados para a publicação deste número de Infarma - Ciências Farmacêuticas seguiram um rigoroso critério de avaliação por pares, visando sempre oferecer a nossos leitores textos revestidos de qualidade. Os artigos publicados abordam experiências na atenção primária à saúde, a automedicação e outros aspectos de interesse e relevância para a atuação farmacêutica. Apesar de retratarem experiências brasileiras, os resultados obtidos são de interesse internacional, podendo servir de base para outros experimentos, outras avaliações, que certamente terão repercussão na melhoria da atenção à saúde.

Os editores de Infarma - Ciências Farmacêuticas esperam que além de ser uma fonte de informação e conhecimento, os artigos publicados estimulem a multiplicação de experiências com abordagem científica, gerando novos resultados a serem publicados, alimentando assim uma roda-viva de ações, e relatos, contribuindo com ciência e com a atuação farmacêutica de qualidade.

Sejam benvindos e tenham uma ótima leitura. 